\title{
Uteroplacental insufficiency down regulates insulin receptor and affects expression of key enzymes of long-chain fatty acid (LCFA) metabolism in skeletal muscle at birth

\author{
Daniela Germani, Antonella Puglianiello and Stefano Cianfarani*
}

Address: Department of Public Health and Cell Biology, Tor Vergata University, 00133 Rome, Italy

Email: Daniela Germani - germani@med.uniroma2.it; Antonella Puglianiello - apuglianiello@med.uniroma2.it; Stefano Cianfarani* - stefano.cianfarani@uniroma2.it

* Corresponding author

Published: 18 May 2008

Cardiovascular Diabetology 2008, 7:14 doi:10.1186/1475-2840-7-14

This article is available from: http://www.cardiab.com/content/7/1/14

(c) 2008 Germani et al; licensee BioMed Central Ltd.

This is an Open Access article distributed under the terms of the Creative Commons Attribution License (http://creativecommons.org/licenses/by/2.0), which permits unrestricted use, distribution, and reproduction in any medium, provided the original work is properly cited.
Received: 18 April 2008

Accepted: 18 May 2008

\begin{abstract}
Background: Epidemiological studies have revealed a relationship between early growth restriction and the subsequent development of insulin resistance and type 2 diabetes. Ligation of the uterine arteries in rats mimics uteroplacental insufficiency and serves as a model of intrauterine growth restriction (IUGR) and subsequent developmental programming of impaired glucose tolerance, hyperinsulinemia and adiposity in the offspring. The objective of this study was to investigate the effects of uterine artery ligation on the skeletal muscle expression of insulin receptor and key enzymes of LCFA metabolism.
\end{abstract}

Methods: Bilateral uterine artery ligation was performed on day 19 of gestation in Sprague-Dawley pregnant rats. Muscle of the posterior limb was dissected at birth and processed by real-time RTPCR to analyze the expression of insulin receptor, ACC $\alpha, A C C \beta$ (acetyl-CoA carboxylase alpha and beta subunits), ACS (acyl-CoA synthase), AMPK (AMP-activated protein kinase, alpha2 catalytic subunit), CPTIB (carnitine palmitoyltransferase-I beta subunit), MCD (malonyl-CoA decarboxylase) in 14 sham and 8 IUGR pups.

Muscle tissue was treated with lysis buffer and Western immunoblotting was performed to assay the protein content of insulin receptor and ACC.

Results: A significant down regulation of insulin receptor protein $(p<0.05)$ and reduced expression of ACS and ACC $\alpha$ mRNA $(p<0.05)$ were observed in skeletal muscle of IUGR newborns. Immunoblotting showed no significant change in ACC $\alpha$ content.

Conclusion: Our data suggest that uteroplacental insufficiency may affect skeletal muscle metabolism down regulating insulin receptor and reducing the expression of key enzymes involved in LCFA formation and oxidation.

\section{Background}

Uteroplacental insufficiency resulting in fetal growth retardation is a common complication of pregnancy and a significant cause of perinatal morbidity and mortality. Epidemiologic studies in humans have shown that impaired intrauterine growth is associated with an 
increased incidence of insulin resistance, type 2 diabetes, and cardiovascular disease in the adult [1-6]. These observations have led to the hypothesis that metabolic and cardiovascular disease in adulthood arises in utero, in part, as a result of changes in the development of key endocrine and metabolic pathways during suboptimal intrauterine conditions associated with impaired fetal growth. This hypothesis has been tested experimentally in a number of species, using a range of techniques to impair fetal growth. Inducing intrauterine growth retardation (IUGR) by placental insufficiency or by undernutrition, stress, or hormone treatment of the mother leads to endocrine and metabolic alterations in the adult offspring in several species [7]. However, the mechanisms by which an abnormal uterine milieu leads to the development of diabetes in adulthood are not known. To investigate potential sequelae of IUGR and the underlying mechanisms, ligation of the uterine arteries in rats has been used as an animal model of uteroplacental insufficiency leading to growth retarded fetuses with a metabolic profile very similar to that of IUGR human fetuses $[8,9]$. We have recently shown that uteroplacental insufficiency, obtained by uterine artery ligation, which leads to IUGR pups, affects the expression of specific hypothalamic lipid sensing genes such as the CPT1 isoform $\mathrm{C}$, and acetyl-CoA carboxylase (ACC) isoforms alpha and beta [10].

Insulin resistance and type 2 diabetes are characterized by hyperglycemia with hyperinsulinemia, a reduced ability to oxidize fat, and an accumulation of fat within skeletal muscle $[11,12]$. This increase in muscle fat content is highly associated with insulin resistance $[13,14]$. Recently, perturbed skeletal muscle insulin signaling has been reported in adult growth restricted rats [15].

In this study we focused on the hypothesis that uteroplacental insufficiency may affect skeletal muscle metabolic pathways altering the expression of insulin receptor and of key enzymes of intramuscular lipid metabolism.

\section{Methods \\ Animal model}

Time-dated Sprague-Dawley pregnant rats (Harlan Sprague Dawley, Inc.) were individually housed under standard conditions and allowed free access to standard chow and water. On day 19 of gestation (term is 22 days) the maternal rats were anesthetized with intramuscular injections of xylazine $(8 \mathrm{mg} / \mathrm{Kg})$ and ketamime $(40 \mathrm{mg} /$ $\mathrm{kg}$ ) (Sigma-Aldrich, St. Louis, MO), and the abdomen was opened along the midline. Suture was placed around both uterine arteries, then either tied or withdrawn before closing the abdomen $[8,9]$. Dams recovered quickly from uterine artery ligation $(\mathrm{n}=4)$ and sham procedures $(\mathrm{n}=$ 4), and resumed feeding the same day. After recovery, rats had ad libitum access to food and water. The pregnant rats were allowed to deliver spontaneously and at birth pups were weighted and killed by cervical dislocation. Posterior limb skeletal muscle tissue was immediately harvested and frozen in liquid nitrogen and stored at $-80^{\circ} \mathrm{C} .14$ sham and 8 IUGR rats from different litters were tested. All procedures complied with Italian regulations for laboratory animal care, according to the guidelines and under supervision of the Animal Technology Station, Interdepartmental Service Center, Tor Vergata University, Rome, Italy.

\section{Plasma assays}

At birth, 14 SHAM and 8 IUGR pups were decapitated, blood was collected and centrifuged at $1900 \times g$ at $4^{\circ} \mathrm{C}$ for $10 \mathrm{~min}$, and plasma was stored at $-80^{\circ} \mathrm{C}$. Glucose and insulin concentrations were measured.

Glucose was determined using a colorimetric commercial kit (SigmaChemical Co.). Plasma insulin concentrations were measured in duplicate by a rat/mouse insulin ELISA kit, using rat insulin as the standard (Linco Research, St. Charles, MO) according to the manufacturer's instructions. The intraassay CV was $1.2-8.4 \%$, the interassay CV was $6.0-17.9 \%$, and the sensitivity limit was $0.2 \mathrm{ng} / \mathrm{mL}$.

\section{RNA isolation and CDNA synthesis}

Total RNA was extracted using TriPure (Roche Applied Science) according to the manufacturer's instructions and quantified in duplicate using ultraviolet absorbance at $260 \mathrm{~nm}$. Gel electrophoresis confirmed the integrity of the samples. $1 \mu \mathrm{g}$ RNA, pretreated with RNase free DNase (Invitrogen Co.) was transcribed into the complementary DNA using the High-Capacity cDNA Archive Kit (Applied Biosystems) in a final volume of $50 \mu \mathrm{l}$ following the manufacturer's protocol. To minimize variation in the reverse transcription reaction, all RNA samples from a single experimental setup were reverse transcribed simultaneously.

\section{Real-time RT-PCR}

We explored the expression of key enzymes that regulate fatty acid metabolism in the muscle. Real-time RT-PCR was performed on an ABI PRISM 7300 Sequencer Detector (Applied Biosystems). PCR primers and TaqMan probes to amplify and detect ACC $\alpha$, ACC $\beta$, ACS, AMPK, CPT1B, $\mathrm{MCD}$, Insulin receptor and the housekeeping gene $18 \mathrm{~S}$ were commercially available as inventoried assay (Assayon-demand Gene Expression Product; Applied Biosystems).

Prior to performing real-time PCR, primer and probe concentrations were determined to demonstrate their specificity and optimal reaction condition. $18 \mathrm{~S}$ was used as an internal control for differences in cDNA loading. Before the use of $18 \mathrm{~S}$ as a control, parallel serial dilution of cDNA 
were quantified to prove the validity of using $18 \mathrm{~S}$ as an internal control.

The real-time RT-PCR amplification was performed in skeletal muscle tissues from fourteen SHAM and eight IUGR rats. Experiments were performed in triplicate using 96-well tray and optical adhesive covers (Applied Biosystems) in a final reaction mixture of $20 \mu \mathrm{l}$ containing $3 \mu \mathrm{l}$ of undiluted cDNA. Real-time PCR was performed using Platinum Quantitative PCR SuperMix-UDG with ROX (Invitrogen Co.). The cycling consisted of $2 \mathrm{~min}$ at $50^{\circ} \mathrm{C}$, $2 \mathrm{~min}$ at $95^{\circ} \mathrm{C}$ followed by 40 cycles of $95^{\circ} \mathrm{C}$ for $15 \mathrm{sec}$ and $60^{\circ} \mathrm{C}$ for $45 \mathrm{sec}$. Determination of reaction efficiency was routinely used as an internal quality control for adequate assay performance. Crossing of threshold $(\mathrm{Ct})$ values obtained for the target gene were normalized against each individual $18 \mathrm{~S}$ value which was run in the same well of the real time RT-PCR run. Relative quantification of PCR products was performed using Relative Quantification Study software (Applied Biosystems). Results are expressed in raw relative quantification $(R Q) \pm$ standard errorrs.

\section{Western immunoblotting}

Tissues were homogenized in ice with lysis buffer $(50 \mathrm{mM}$ Hepes pH 7.4, $150 \mathrm{mM} \mathrm{NaCl}, 10 \mathrm{mM} \mathrm{NaF}, 1 \mathrm{mM} \mathrm{Na}_{3} \mathrm{VO}_{4}$, $10 \%$ glycerol, $0.5 \%$ Triton $\times-100,5 \mathrm{mM}$ EDTA, $10 \mu \mathrm{l} / \mathrm{ml}$ cocktail protease inhibitors). Lysates were clarified by centrifugation at $13,000 \mathrm{~g}$ ( 30 minutes, $4^{\circ} \mathrm{C}$ ), and protein concentration in the supernatant were determined by the Bradford assay (Bio-Rad Laboratories, CA, USA) using bovine serum albumin as a standard. Eighty micrograms of the extracted proteins were separated by SDS-PAGE on 3-8\% Tricine gel (Bio-Rad Laboratories, CA, USA) and blotted onto ECL nitrocellulose membrane (Amersham Biosciences UK, Ltd., Little Chalfont, Buckinghamshire, UK). The filter was blocked with $5 \%$ non-fat dry milk in TBS- $0.1 \%$ Tween 20 and then incubated with ACC rabbit polyclonal antibody (Cell Signaling Technology Inc. Danvers, MA) and insulin-R $\beta$ rabbit polyclonal antibody (Santa Cruz). After several washes in PBS-0.1\% Tween 20, horseradish peroxidase-conjugated secondary antibody $(1: 5,000)$ (Amersham) was added for 1 hour at RT. The labelled bands were detected using Amersham ECL western blotting system according to manufacturer's specifications. After protein detection, membranes were stripped with Restore Western Blot Stripping Buffer (Pierce, Rockford IL) and re-blotted with rabbit HRP-conjugated actin antibody (1:1000) (Santa Cruz). Densitometry analysis of bands was performed using a Image Quant 5 software (Molecular Dynamics).

\section{Statistical analysis}

Statistical analysis was performed using Sigma Plot for Windows Version 13.0 (SPSS, Inc, Chicago, IL, USA). Dif- ferences in gene expression between sham and IUGR rats were analyzed with one-way ANOVA. Differences between means from plasma assays and densitometric analyses were assessed by unpaired two-tailed $t$ test. Differences were considered statistically significant at $p<$ 0.05 .

\section{Results}

\section{Animal weights and metabolic profile}

Birth weights of IUGR animals were significantly lower than those of controls (SHAM) (mean weight \pm SD: $4.0 \pm$ 0.57 versus $6.5 \pm 0.32 \mathrm{~g}, p<0.001)$. No significant differences were observed in blood glucose $(63.9 \pm 13$ vs $62.9 \pm$ $21.5 \mathrm{mg} / \mathrm{dL})$ and insulin $(0.34 \pm 0.15$ vs $0.36 \pm 0.16 \mathrm{ng} /$ $\mathrm{mL}$ ) levels.

\section{Insulin Receptor}

Although a tendency toward a decrease of insulin receptor mRNA expression was noted (20\% less), these changes did not achieve statistical significance (Figure 1).

Immunoblot analysis indicated a significant down regulation of insulin receptor in skeletal muscle of IUGR animals when compared with SHAM (control) ( $\mathrm{p}<0.05$, Figure 2).

\section{Expression of LCFA metabolism regulatory enzymes}

LCFAs act as nutrient abundance signals in the muscle. The expression of key enzymes that regulate muscle LCFA metabolism was assessed. The expression of ACC $\alpha$ and ACS mRNA levels was significantly reduced (by $54 \%$ and $66 \%$ respectively, $\mathrm{p}<0.05$ ) in skeletal muscle of IUGR rats at birth (Figure 3), whereas no significant differences in

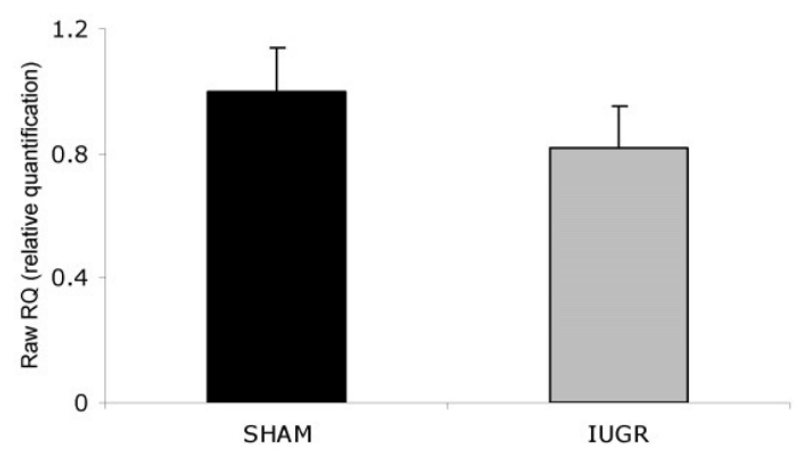

\section{Figure I}

Insulin receptor $m R N A$ expression in skeletal muscle of SHAM $(n=14)$ and IUGR rats $(n=8)$. Transcripts were measured by real-time RT-PCR using appropriate primers and normalized to I8S mRNA. Data are expressed as relative quantification vs. SHAM group $(R Q=1)$. Bars represent standard errors. 
A

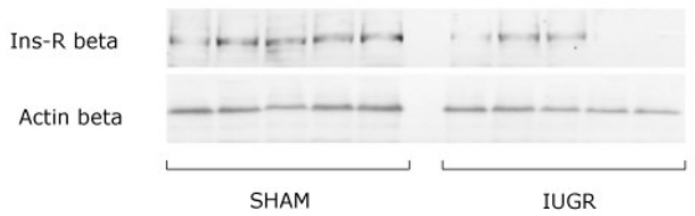

B

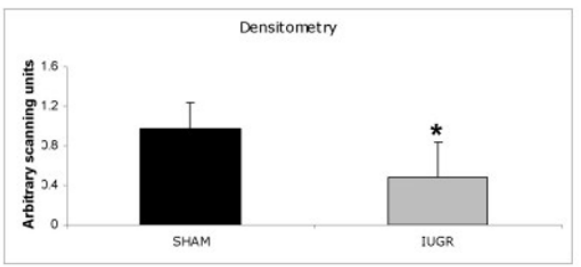

Figure 2

Insulin receptor beta subunit protein expression in skeletal muscle of SHAM $(n=14)$ and IUGR rats $(n=$ 8) on day 0 . A, Western immunoblotting analysis; $B$, densitometric analysis. ${ }^{*} \mathrm{P}<0.05$.

the expression of ACC $\beta, A M P K$, and MCD were observed. Expression of muscle specific $C P T 1 B$ was measured by quantitative RT-PCR but no significant difference between IUGR and SHAM pups was found.

ACC $\alpha$ immunoblotting analysis showed no differences between IUGR and SHAM animals thus suggesting a posttranscriptional regulation (Figure 4). ACS immunoblotting analysis couldn't be performed for unavailability of the specific antibodies.

\section{Discussion}

Uteroplacental insufficiency limits availability of substrates to the fetus and retards growth during gestation, ultimately leading to IUGR. Alterations in the intrauterine milieu have a profound impact on glucose homeostasis in the offspring, culminating in the development of insulin resistance, glucose intolerance and type 2 diabetes in adulthood.

The etiology of insulin resistance within skeletal muscle in the human with type 2 diabetes is multifactorial, involving impairments in hormonal signaling, enzyme and transporter activity, and substrate availability. Previous studies also implicated decreased oxidative capacities of skeletal muscle of human diabetics as contributory to insulin resistance [16].

To investigate the effects of uteroplacental insufficiency on the expression of insulin receptor in muscle, we studied an animal model of intrauterine growth retardation obtained by bilateral uterine artery ligation. In this model,

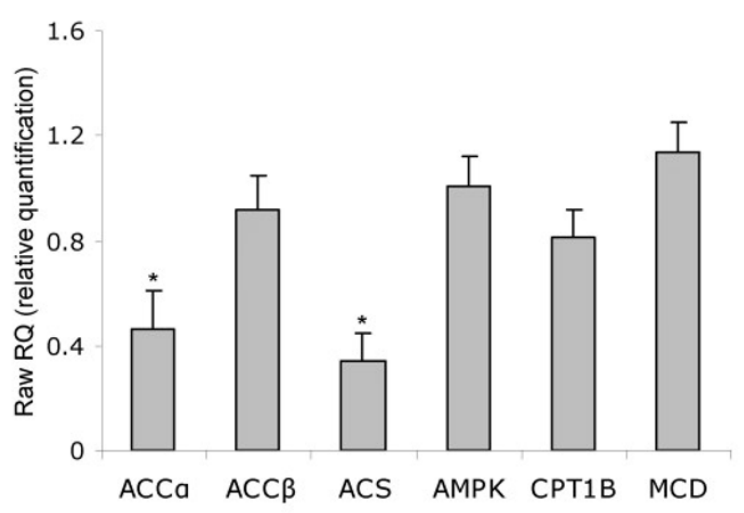

Figure 3

Expression of acetyl-CoA carboxylase isoenzyme alpha (ACC $\alpha)$ and beta (ACC $\beta$ ), acyl-CoA synthase (ACS), AMP-activated protein kinase (AMPK), carnitine palmitoyltransferase-I isoenzyme B (CPTIB), malonyl-CoA decarboxylase (MCD), in IUGR rat skeletal muscle. Transcripts were measured by real-time RT-PCR using appropriate primers and normalized to I8S mRNA. Data are expressed as relative quantification vs. SHAM group $(R Q=I)$. Bars represent standard errors. $* \mathrm{P}<$ 0.05 .

the resulting uteroplacental insufficiency leads to growth retarded fetuses with a metabolic profile very similar to that of IUGR human fetuses [8,9]. These animals exhibit impaired oxidative phosphorylation in skeletal muscle [17], mild peripheral insulin resistance and $\beta$-cell secretory defects very early in life but have adequate compensatory insulin secretion for several weeks [18]. However, eventually, $\beta$-cell compensation fails, and overt diabetes occurs at age 3-6 months [9]. More recently, it has been described in the same animal model that ligated offspring showed impaired glucose tolerance from the age of 15 weeks as well as elevated glycosylated hemoglobin and corticosterone levels [19].

Our data show for the first time reduced protein levels of insulin receptor in skeletal muscle of IUGR animals. The lack of statistical significance in insulin receptor mRNA expression is probably due to the relative low number of examined samples. Most of previous studies focused on downstream effectors of insulin actions in peripheral tissues without determining insulin receptor expression. In rat model, Ozanne et al. [20] showed that maternal protein restriction leads to muscle insulin resistance. Soleus muscle from growth restricted offspring had similar basal glucose uptakes compared with the control group, but whilst insulin stimulated glucose uptake into control muscle, it had no effect on growth restricted offspring 
A

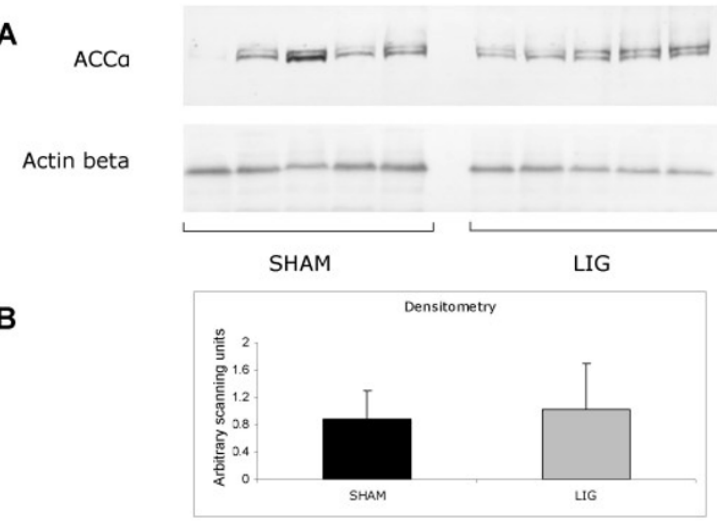

Figure 4

Acetyl-CoA carboxylase isoenzyme alpha (ACC $\alpha$ ) protein expression in skeletal muscle of SHAM $(n=$ $14)$ and IUGR rats $(n=8)$ on day 0 . A, western immunoblotting analysis; $B$, densitometric analysis.

muscle. This impaired insulin action was not related to changes in expression of either the insulin receptor or glucose transporter 4 (GLUT4). However, growth restricted offspring muscle expressed significantly less of the zeta isoform of protein kinase $\mathrm{C}$ (PKC $\zeta$ ) compared with controls. This PKC isoform has been shown to be positively involved in GLUT4-mediated glucose transport. We have used a different model of intrauterine growth restriction based upon uterine artery ligation in which blood flow to the fetus is not ablated but reduced to a similar degree to that observed in human pregnancies complicated by uteroplacental insufficiency. Furthermore, whilst Ozanne et al. [20] studied 15-month-old animals, we investigated rats at birth. The use of only hind limb skeletal muscle might represent a limiting factor since an important difference between type 1 (slow) and type 2 (fast) fibers could exist. However, at birth it is practically impossible to select muscle fibers.

In humans, Jaquet et al. [21] demonstrated that insulin resistance is associated with an impaired regulation of GLUT4 gene expression by insulin in IUGR-born subjects in both skeletal muscle and adipose tissue.

Impairment of muscle fat metabolism is highly associated with insulin resistance. Our study shows for the first time that uteroplacental insufficiency leads to reduced ACS and ACC $\alpha$ mRNA expression in skeletal muscle at birth. In intramuscular lipid metabolism, ACS is the key enzyme for converting free fatty acids into LCFA-CoA. ACC catalyzes the formation of malonyl-CoA, an essential sub- strate for fatty acid synthesis in lipogenic tissues and a key regulatory molecule in muscle, brain, and other tissues [22]. Three CPT1 isoforms with various tissue distributions and encoded by distinct genes have been identified: liver (CPT1A) [23], muscle (CPT1B) [24], and brain (CPT1C) [25] Cellular levels of malonyl-CoA repress CPT1 activity and decrease LCFA-CoAs oxidation. Therefore, the final effect of reduced expression of both ACS and ACC $\alpha$ would be the decrease of intramuscular LCFAs. This finding is consistent with our recent study in hypothalamus of IUGR rats, showing significant decreased ACC $\alpha$ and ACC $\beta$ expression at birth [10]. Taken together these findings suggest that intrauterine programming may affect key enzymes of lipid metabolism at multiple levels. In muscle, however, ACC $\alpha$ protein content was not affected thus suggesting post-transcriptional regulation.

Lipids are implicated in the development of insulin resistance in skeletal muscle. This seems to be linked to an imbalance between lipid supply and lipid oxidation, the latter being related to decreased mitochondrial oxidative capacity in states of insulin resistance [26]. In humans, it has been described that during physiological hyperglycemia with hyperinsulinemia and maintained FFA concentrations (i.e., a condition that mimics the insulin-resistant state), human skeletal muscle malonyl-CoA concentrations are significantly increased and are directly associated with a reduction in LCFA oxidation and functional CPT-1 activity [27].

As LCFA oxidative capacity in mitochondria is low in subjects with insulin resistance [20,28-32], mitochondrial dysfunction and thereby decreased lipid oxidation has been considered to play a key role in the development of insulin resistance. Lane et al. reported an increase in triglyceride levels in IUGR rats [33] Accordingly, a connection between mitochondrial dysfunction, increased intramuscular triacylglycerol levels, and insulin resistance has been described in insulin-resistant offspring of patients with type 2 diabetes [34].

LCFAs may influence glucose metabolism by multiple mechanisms. LCFAs inhibit hexokinase activity [35] thus reducing glucose metabolism. They are also a substrate for the synthesis of ceramide which is increased in muscle of insulin-resistant rats [36]. LCFAs may interfere with insulin signaling by activating protein kinase C. PKC in turn inhibits insulin signaling by phosphorylation of the serine residues on the insulin receptor $[37,38]$ and insulin receptor substrate-1 (IRS-1) [39], thus inhibiting the tyrosine phosphorylation of IRS-1. Patients with type 2 diabetes have increased PKC protein levels in the rectus abdominal muscle [40] and decreased muscle insulin receptor tyrosine kinase activity, which could be restored by phosphatase treatment in vitro, possibly suggesting 
increased serine phosphorylation of the insulin receptor due to increased PKC activity [37].

We speculate that intrauterine limited supply of substrates secondary to uteroplacental insufficiency may lead to down regulation of insulin receptor in skeletal muscle. We hypothesize that reduced intramuscular content of LCFAs secondary to reduced expression of both ACS and ACC may represent a transient compensatory mechanism to counteract insulin resistance during early postnatal life.

\section{Conclusion}

Uteroplacental insufficiency may affect skeletal muscle metabolism down regulating insulin receptor and reducing the expression of key enzymes involved in LCFA formation and oxidation. We speculate that decreased intramuscular lipid accumulation may represent a transient compensatory mechanism to counteract insulin resistance.

\section{Abbreviations}

ACC: acetyl-CoA carboxylase; ACS: acyl-CoA synthase; AMPK: AMP-activated protein kinase; CPT1: carnitine palmitoyltransferase-1; IUGR: intrauterine growth retardation; LCFA: long-chain fatty acid; MCD: malonyl-CoA decarboxylase.

\section{Competing interests}

The authors declare that they have no competing interests.

\section{Authors' contributions}

DG: participated in the design of the study, carried out the experiments, performed statistical analysis and reviewed the manuscript. AP: carried out the experiments and reviewed the manuscript. SC: conceived the study, supervised the project and drafted the manuscript. He is the corresponding Author of the paper. All Authors read and approved the final manuscript.

\section{References}

I. Barker DJ, Winter PD, Osmond C, Margetts B, Simmonds SJ: Weight in infancy and death from ischaemic heart disease. Lancet 1989, 2:577-580.

2. Barker DJ, Osmond C, Golding J, Kuh D, Wadsworth ME: Growth in utero, blood pressure in childhood and adult life, and mortality from cardiovascular disease. BMJ 1989, 298:564-567.

3. Barker DJ, Hales CN, Fall CH, Osmond C, Phipps K, Clark PM: Type 2 (non-insulin-dependent) diabetes mellitus, hypertension and hyperlipidemia (syndrome $X$ ): relation to reduced fetal growth. Diabetologia 1993, 36:62-67.

4. Barker DJ: Fetal origins of coronary heart disease. BMJ I995, 3 I I:I7I-I74.

5. Eriksson JG, Forsen T, Tuomilehto J, Osmond C, Barker DJ: Early growth and coronary heart disease in later life: a longitudinal study. Br Med J 2001, 322:949-953.

6. Geremia C, Cianfarani S: Insulin sensitivity in children born small for gestational age (SGA). Rev Diabet Stud 2004, I:58-65.

7. Fowden AL, Giussani DA, Forhead AJ: Endocrine and metabolic programming during intrauterine development. Early Hum Dev 2005, 8 I:723-734.
8. Unterman T, Lascon R, Gotway M, Oehler D, Gounis A, Simmons RA, Ogata ES: Circulating levels of insulin-like growth factor binding protein-I (IGFBP-I) and hepatic mRNA are increased in the small for gestational age fetal rat. Endocrinology 1990, I 27:2035-2037.

9. Simmons RA, Templeton LJ, Gertz SJ: Intrauterine growth retardation leads to the development of type 2 diabetes in rat. Diabetes 2001, 50:2279-2286.

10. Puglianiello A, Germani D, Antignani S, Scalia Tomba G, Cianfarani S: Changes in the expression of hypothalamic lipid sensing genes in rat model of intrauterine growth retardation (IUGR). Pediatr Res 2007, 6 I:433-437.

II. Kelley DE, Mandarino LJ: Hyperglycemia normalizes insulin stimulated skeletal muscle glucose oxidation and storage in non insulin dependent diabetes mellitus. J Clin Invest 1990, 86: 1999-2007.

12. Mandarino LJ, Consoli A, Kelley DE: Effects of obesity and NIDDM on glucose and insulin regulation of substrate oxidation in skeletal muscle. Am J Physiol 1996, 270:E463-E470.

13. Kelley DE, Goodpaster BH: Skeletal muscle triglyceride. An aspect of regional adiposity and insulin resistance. Diabetes Care 200I, 24:933-94I.

14. Pan DA, Lillioja S, Kriketos AD, Milner MR, Baur LA, Bogardus C, Jenkins $A B$, Storlien LH: Skeletal muscle triglyceride levels are inversely related to insulin action. Diabetes 1997, 46:983-988.

15. Oak SA, Tran C, Pan G, Tramotharan M, Devaskar SU: Perturbed skeletal muscle insulin signaling in the adult female intrauterine growth-restricted rat. Am J Physiol Endocrinol Metab 2006, 290:EI32I-EI330.

16. Simoneau J-A, Kelley DE: Altered glycolytic and oxidative capacities of skeletal muscle contribute to insulin resistance in NIDDM. J Appl Physiol 1997, 83: I66-I7I.

17. Lane RH, Maclennan NK, Daood MJ, Hsu JL, Janke SM, Pham TD, Puri AR, Watchko JF: IUGR alters postnatal rat skeletal muscle peroxisome proliferator-activated receptor- $\gamma$ coactivator-I gene expression in a fiber specific manner. Pediatr Res 2003, 53:994-1000.

18. Selak MA, Storey BT, Peterside I, Simmons RA: Impaired oxidative phosphorylation in skeletal muscle of intrauterine growthretarded rats. Am J Physiol Endocrinol Metab 2003, 285:EI30-E I37.

19. Nusken K-D, Dotsch J, Rauh M, Rascher W, Schneider H: Uteroplacental insufficiency after bilateral uterine artery ligation in the rat: impact on postnatal glucose and lipid metabolism and evidence for metabolic programming of the offspring by sham operation. Endocrinology .

20. Ozanne SE, Olsen GS, Hansen LL, Tingey KJ, Nave BT, Wang CL, Hartil K, Petry CJ, Buckley AJ, Mosthaf-Seedorf L: Early growth restriction leads to down regulation of protein kinase $C$ zeta and insulin resistance in skeletal muscle. J Endocrinol 2003, I 77:235-24I.

2I. Jaquet D, Vidal H, Hankard R, Czernichow P, Levy-Marchal C: Impaired regulation of glucose transporter 4 gene expression in insulin resistance associated with in utero malnutrition. J Clin Endocrinol Metab 200I, 86:3266-327I.

22. Brownsey RW, Boone AN, Elliott JE, Kulpa JE, Lee WM: Regulation of acetyl-CoA carboxylase. Biochem Soc Trans 2006, 34:223-227.

23. Britton CH, Schulz RA, Zhang B, Esser V, Foster DW, McGarry JD: Human liver mitochondrial carnitine palmitoyltransferase I: characterization of its cDNA and chromosomal localization and partial analysis of the gene. Proc Natl Acad Sci USA 1995, 92:1984-1988.

24. Yamazaki N, Shinohara $Y$, Shima A, Yamanaka $Y$, Terada $\mathrm{H}$ : Isolation and characterization of cDNA and genomic clones encoding human muscle type carnitine palmitoyltransferase I. Biochim Biophys Acta 1996, I307:157-161.

25. Price N, Leij F van der, Jackson V, Corstorphine C, Thomson R, Sorensen A, Zammit V: A novel brain-expressed protein related to carnitine palmitoyltransferase I. Genomics 2002, 80:433-442.

26. Kiens B: Skeletal muscle lipid metabolism in exercise and insulin resistance. Physiol Rev 2006, 86:205-243.

27. Rasmussen BB, Holmbäck UC, Volpi E, Morio-Liondore B, PaddonJones $D$, Wolfe RR: Malonyl coenzyme $A$ and the regulation of functional carnitine palmitoyltransferase-I activity and fat oxidation in human skeletal muscle. J Clin Invest 2002, I 10:1687-1693. 
28. Colberg SR, Simoneau JA, Thaete FL, Kelley DE: Skeletal muscle utilization of free fatty acids in women with visceral obesity. J Clin Invest 1995, 95: 1846-1853.

29. Goodpaster BH, Theriault R, Watkins SC, Kelley DE: Intramuscular lipid content is increased in obesity and decreased by weight loss. Metabolism 2000, 49:467-472.

30. Kelley DE, He J, Menshikova EV, Ritov VB: Dysfunction of mitochondria in human skeletal muscle in type 2 diabetes. Diabetes 2002, 5 I:2944-2950.

31. Ritov VB, Menshikova EV, He J, Ferrell RE, Goodpaster BH, Kelley DE: Deficiency of subsarcolemmal mitochondria in obesity and type 2 diabetes. Diabetes 2005, 54:8-I4

32. Simoneau JA, Veerkamp JH, Turcotte LP, Kelley DE: Markers of capacity to utilize fatty acids in human skeletal muscle: relation to insulin resistance and obesity and effects of weight loss. FASEB J 1999, I 3:205 I-2060.

33. Lane RH, Kelley DE, Ritov VH, Tsirka AE, Gruetzmacher EM: Altered expression and function of mitochondrial beta-oxidation enzymes in juvenile intrauterine-growth-retarded rat skeletal muscle. Pediatr Res 200I, 50:83-90.

34. Petersen KF, Dufour S, Befroy D, Garcia R, Shulman GI: Impaired mitochondrial activity in the insulin-resistant offspring of patients with type 2 diabetes. N Engl I Med 2004, 350:664-67I.

35. Thompson AL, Cooney GJ: Acyl-CoA inhibition of hexokinase in rat and human skeletal muscle is a potential mechanism of lipid-induced insulin resistance. Diabetes 2000, 49: I76I-I765.

36. Turinsky J, O'Sullivan DM, Bayly BP: I,2-Diacylglycerol and ceramide levels in insulin-resistant tissues of the rat in vivo. J Biol Chem 1990, 265: 16880-16885.

37. Itani SI, Zhou Q, Pories WJ, MacDonald KG, Dohm GL: Involvement of protein kinase $\mathbf{C}$ in human skeletal muscle insulin resistance and obesity. Diabetes 2000, 49:II353-I358.

38. Takayama S, White MF, Kahn CR: Phorbol ester-induced serine phosphorylation of the insulin receptor decreases its tyrosine kinase activity. J Biol Chem 1988, 263:3440-3447.

39. Ravichandran LV, Esposito DL, Chen J, Quon MJ: Protein kinase Czeta phosphorylates insulin receptor substrate- I and impairs its ability to activate phosphatidylinositol 3-kinase in response to insulin. J Biol Chem 200I, 276:3543-3549.

40. Itani SI, Pories WJ, MacDonald KG, Dohm GL: Increased protein kinase $\mathbf{C}$ theta in skeletal muscle of diabetic patients. Metabolism 200I, 50:553-557.
Publish with Biomed Central and every scientist can read your work free of charge

"BioMed Central will be the most significant development for disseminating the results of biomedical research in our lifetime. "

Sir Paul Nurse, Cancer Research UK

Your research papers will be:

- available free of charge to the entire biomedical community

- peer reviewed and published immediately upon acceptance

- cited in PubMed and archived on PubMed Central

- yours - you keep the copyright
BioMedcentral 